\title{
How effective are the different principal \\ organs of the UN in aiding the Venezuela
}

\section{crisis?}

\section{Lei L. Kurotaki}

\section{DOI: 10.26821/IJSRC.9.3.2021.9302}

Ever since Nicolás Maduro came into power, the Latin American nation of Venezuela fell into a deep political, economic and humanitarian crisis that has not yet been resolved to this day. This paper examines the different ways Venezuela has been affected and how the crisis is being handled by the United Nations. Various sub-branches of this world-renowned Intergovernmental Organization aims to resolve the issues related to their respective fields, and together they are supposed to maintain peace and help find victims security. However, in closely analyzing the history, and how the respective fields have dealt with current situations, the question of how effective these organs are, arises. The Venezuelan crisis has long been a topic of concern to the world and the U.N. but it seems that more needs to be done beyond conferences and simple aid.

Venezuela was once South America's most prosperous country. Venezuela had been one of the most educated urban populations, with access to clean drinking water, electricity, and sanitation facilities. The once affluent nation possessed the largest proven fossil-fuel reserves globally (Naím\& Toro, 2018). But now, the country's economy is in shambles, shrinking at an alarming rate, with the inflation rate spiraling out of control (Kiger, 2019). Violence, political unrest, and poverty set their roots with millions out of work and unable to pay for day-to-day necessities. Venezuela ranks 179th in the 2020 economic freedom index (2020 Index of Economic Freedom) which is a reflection of the country's plummeting economy. The crisis has progressively worsened during the Maduro regime (Escobari, 2019). The printing of money driving inflation, fixed price of certain products, and a lack of foreign exchange all factored in to create a cycle that went out of control, and it is safe to say that the collapse of the economy isn't a result of a civil war or natural disaster but rather due to mismanagement and financial negligence (Hodgkinson et al., 2016). Venezuela is plagued by the suppression of democratic values. The key to economic restoration is a smooth transition of government, establishment of democratic processes, restructuring public debt, end of hyperinflation, and repair of trust by building institutions (Brown, 2018).

\section{Background}

Venezuela emerged from the ashes of the Gran Colombia in 1830 alongside New Granada and Ecuador. Since then, the country has been ruled by benevolent military men, who focused on creating and strengthening the oil economy. The democratic process did not become land law until 1959 (Gott, 2000). The democracy lasted until Hugo Chávez's rule (1999-2013) when he asserted a complete hold over the branches of government. United Socialist Party of Venezuela (Partido SocialistaUnido de Venezuela or PSUV) rose to power, and for two decades, it has been gaining influence in the judiciary and electoral council. However, his hand-picked 
successor Nicolás Maduro completed the destruction of democratic institutions in 2017 by establishing a repressive authoritarian dictatorship. The socialist policies, hyperinflation, and shortage of supplies led to economic decline (Gamboa, 2017), kicking off Latin America's worst migration crisis prompting 4.5 million people to leave their homes (Bean, 2016). With the censure of the 2018 fraudulent re-election under the Maduro regime, Juan Guaidó, the head of the National Assembly, stepped up to oppose the dictatorship. In December 2016, the opposition won the majority in the National Assembly, focusing on economic reforms. In response to the opposition, the Maduro administration created a National Constituent Assembly, to replace the original coalition with hand-picked Maduro supporters, overriding the National Assembly. While Maduro was declared to have won the 2018 re-election, the opposition and the general publicdismissed the election results as rigged. Guaidó, the opposition leader, has called Maduro a 'usurper' and, with the National Assembly's support, declared himself as the interim president in 2019.

While Guaidó rightfully invoked the constitutional right that allows him to step in as acting president if irregularities were found, the Maduro administration remains in power, characterizing Guaidó's move as 'foreign interference in internal affairs' and a Coup d'Etat (News Wires, 2019). More than 50 countries have recognized the Guaidó presidency, including Argentina, Brazil, Canada, United States, Mexico, France, Germany, Guatemala, Israel, Paraguay, Peru, Spain, and Vatican City. International organizations like the European Union, Mercosur, and the Organization of American States (OAS) have also come forward in support of Guaidó. China, Russia, and Turkey on the other hand support Maduro, either in opposition to the U.S. or to secure their investment in the region (CIA, 2020). The Lima Group and the International Conference on the Situation in Venezuela have declared either neutrality or partial support to Maduro. The United Nations' response so far has been neutral, and all efforts have been rendered mute without reaching a consensus on the subject.

Under whose leadership Venezuela's future lies upon is pretty clear to the two sides: countries who support Maduro and countries who view Guido as the legitimate president. But the world being unable to come to an agreement over the Venezuelan presidency doesn't do any good for Venezuela and continues to worsen the instability of the government which stirred the crisis in the first place.

\section{Chaos, Economy, and Humanitarian Crisis}

The fall of the once-mighty nation is neither a result of natural disaster nor civil war but has been called 'mismanagement' at best (Kiger. P. 2019). The country's GDP has fallen by 245 billion dollars since 2018, and the trend shows an $83 \%$ further decline in the economy as shown in Figure 1 below (Pelcher, 2020).

Venezuela's economic capacity has been dependent on oil reserves since the 1910s, so inflation amid the chaos of the 2015 downfall of oil prices caused a complete breakdown of the currency (Mu, X. \& Hu, G. 2018). This resulted in almost 5.5 million people having to leave the region and find opportunities elsewhere. Maduro continued the policies associated with "Bolivarian missions", a series of government-funded social programs aimed to reduce poverty, which was first implemented by Chávez (McCarthy, J. 2006). However, as Tulane University professor David Smilde says, "These were policies that were completely unsustainable, they were based on the continual growth of income from oil" (Ofman, D. 2016). Consequently, when the oil prices rose and Venezuela's revenue declined, Venezuela's lack of economic diversity and mismanagement has led the country into deep debt and a national crisis. The Maduro regime has been accused of retaining power through 
intimidation and disenfranchisement of dissenters and eradicating opposing politicians from their positions (United States Department of State, 2020).

\title{
Venezuela: Gross domestic product (GDP) in current prices from 1984 to 2019 (in billion international dollars)
}

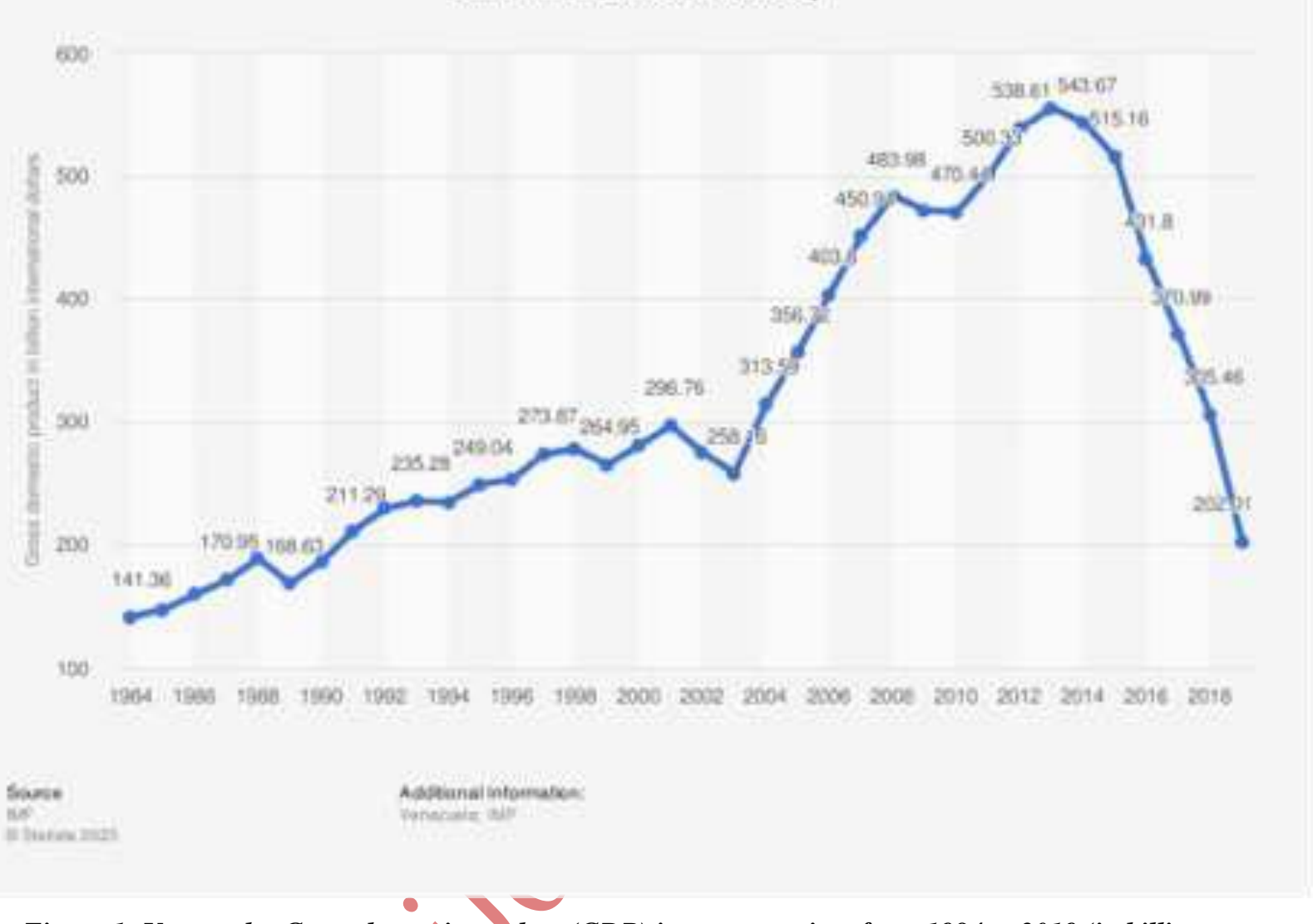

Figure 1: Venezuela: Gross domestic product (GDP) in current prices from 1984 to 2019 (in billion international dollars). Courtesy of (Pelcher, 2020)

Venezuela's crisis has indeed been noticed by the UN and has become a growing concern for powerhouses like the US, UK, China, and Russia, as well as refugee in-takers/countries around them like Mexico, Brazil, Ecuador, and Colombia.

\begin{abstract}
About the U.N.
The International Body of the United Nations was established in 1945 as a non-profit in the wake of World War II, adhering to "the maintenance of international peace and security." (Maintain International Peace. 2020) The organization has 193 member states and consists of six principal organs: The General Assembly, Security Council, Economic and Social Council, The Trusteeship Council, The International Court of Justice, and the Secretariat. The U.N. is also supported by specialized agencies that can navigate the political circle and effectively "encourage cooperation and diplomatic resolutions to global problems. (United Nations, 2020).

The UN addresses a variety of issues, including human rights, gender equality, employment, terrorism, humanitarian aid, sustainability, and climate change. It also plays a vital role in preventative diplomacy, mediation, peace-building, counter-terrorism, and disarmament. The UN has the resources to protect and promote human rights under the International Bill of Human Rights. They are also able to quickly and
\end{abstract}


efficiently deliver humanitarian aid to adults and children who are victims of disaster-struck areas and conflicted regions using a "coordinated, system-wide approach" of UN entities (Deliver Humanitarian Aid. 2020). The U.N. has also introduced the Sustainable Development Goals which all member states adopted in 2015 as a universal call to "end poverty and hunger, increase access to education, address migration, combat climate change, and reduce inequality" (United Nations Sustainable Development Goals. 2020). In these ways, the UN strives to maintain international peace and security, protect human rights, deliver humanitarian aid, promote sustainable development, and uphold international law.

\section{Human Rights Council on the Venezuela Crisis}

The Human Rights Council is a principal organ of the UN that aims to promote and protect human rights. Despite being on a mission to end human atrocities with a quorum of forty-seven member-elect-countries, the Council has been 'unsuccessful' in addressing the Venezuelan crisis, not to mention the staggering human rights violations occurring in Kashmir, Gaza, Armenia, Azerbaijan, Afghanistan, China, Russia, and other developing countries. The problem of failing to address human rights violations can very well be attributed to the arbitrary internal policies of the HRC. In the October 2019 HRC seat election, Venezuela, despite having massive human rights violations, won the position. The election was contested by Costa Rica, a country with a better human-rights record than many of the Latin-American countries (Lederer, E. 2019). U.S. Ambassador to the UN, Kelly Craft, calls it "an embarrassment and tragedy" for Venezuelan civilians (US Embassy Caracas, 2019). Louis Charbonneau, UN director at the Human Rights Watch responds by saying "It's not good for human rights or for the rights council when the worst rights violators get elected ...” (UN: Deny Rights Council Seats to Major Violators. 2020). How will an organization carry out its missions if the very people who make up the body do not uphold those values?

Furthermore, Libya and Sudan, plagued with conflict and war, "won uncontested seats on the council," which suggests hypocrisy, to say the least (Roth, R. 2019). If sitting members of the Council are above the charter, then it raises a red flag and begs the question: how effective is the Human Rights Council?

Additionally, the Council has been called "anti-semitic" and criticized for "obsessively" condemning Israel. (UN Human Rights Council: History \& Overview. 2020), while failing to condemn the Kashmir issue, human rights violations in Myanmar, and China, and calling Sudan "operative".

\section{Security Council's Response to the Crisis}

The Security Council is a principal organ of the U.N. with fifteen members of which five are permanent and ten are elected for 2-year terms by the General Assembly. Permanent seat holders are the United States, the United Kingdom, France, Russia, and China. The Council holds a central and influential position within the UN, with more members than any other international organization. However, the Council has always been in hot water for giving too much leniency and glorifying the agendas of permanent members because these nations have the power to veto and raise or suppress any issue that affects their interests (Yenigun, 2016). There is criticism that the UN isn't genuinely representing today's world because as Sami Hamdi, Editor-in-Chief of the International Interest said "The United Nations reflects the power dynamics of the time of 1945," (TRT World, 2020). The super-powers of post-WWII continue to hold the permanent seats nearly a century later. The council has given little to no representation to nations in Africa, Latin America, Asia, and the Middle East. And 
so far, the permanent members' ability to veto has enabled them to protect their own interests: for example, with the resolutions concerning the Syrian Crisis, Taiwan's independence, and Israel.

The Council may have its own agendas to secure their own interests, but nevertheless, the degree of influence they hold over conflicted regions cannot be ignored and must be kept under close watch. The Council can set up talks, send peace missions, recommend policies, adjust doctrines, impose sanctions, and possesses the authority to use force (De Wet, 2004). With this power, the Council may be the key to finally ending the democratic crisis of Venezuela, and avert a humanitarian crisis that has been boiling for nearly two decades. So far, the issue has been taken to the floor in the $8472^{\text {nd }}$ meeting where it became clear that the majority of the UN representatives did not support the Maduro regime's use of violence and excessive force. Nations worldwide have criticized the Venezuelan government, and even Mr. Fernández de Soto Valderrama, representative of Colombia, called out Maduro for "burning aid that had managed to cross the border" but President Maduro has outright denied the claims and does not acknowledge the crisis at all (United Nations S/PV.8476).

The Security Council's stance is better put into the words of South African representative Mr. Matjila at their 8476th meeting: "Let the people of Venezuela decide their future. All that we can do is help them, but the decisions remain Venezuelan." (United Nations S/PV.8476). The Security Council has the necessary power to deploy peacekeeping troops to deescalate the situation, but the power has been used on very few occasions due to severe backlash on the global political stratosphere. While the charter allows the use of force, the Security Council has majorly focused directives to broker peace through minimaluse of pressure, sanctions, and dialogue (Bahar et al., 2018). There is a disagreement between whether the concern is important enough to be acted upon. The German representative stated, "I disagree with my South African friend - I think that this issue belongs to the Council's agenda." The SC can also not further take the issue because both President Maduro and Guaidó have been supported by powerful allies. Any intervention from the partners can give way to global warfare, restricting the peace talks process.

U.S. representative Mr. Abrams said that "we should respect their Constitution and their sovereignty, which is why we must support Juan Guaidó's interim presidency." And Poland's representative narrated the stance, "we reiterate our recognition of the National Assembly and its President, Mr. Juan Guaidó, as the only legitimate power in Venezuela with a democratic mandate, won in free and fair elections, in line with the Venezuelan Constitution." While the crisis worsens the situation amid the COVID-19 pandemic, the negotiations have been referred to as the only way to overcome the political divide and end the political deadlock (Peace and Security, 2020).

The crisis of democracy originates back to the political and economic instability worsened by the Maduro regime. Poland representative, Ms. Wronecka believed that the conflict's nature is political and hence, the solutions should be political and that there is a need for intervention from the Security Council. Over the recent meeting, the matter revealed that the Maduro regime has burned the aid being delivered across the border, calling it interference and a coup to attempt to overthrow President Maduro. The government announced that they have allegedly caught 13 terrorists' to enter Caracas with the plot to assassinate the president. The official report read, "to increase the spiral of violence, generate chaos and confusion ... and with that lead to a new attempt at a coup d'etat" by Washington. While presenting the U.S. army members: Airan Berry, 41, and Luke Denman, 34 identification papers prompted the restriction crossing of humanitarian aid into the Venezuelan 
borders. (Aljazeera News, 2020) The crisis has been called to be "further exacerbated" by pro-Maduro efforts as more and more Venezuelans suffer from the lack of necessities.

While S.C. holds greater influence on the global political sphere, Maduro's diplomatic ties have not significantly weakened. While the EU, UN, US, UK, Germany, and Mexico have been working to put sanctions on the Maduro administration, China and Russia have strong ties to the government, making it difficult to resolve the conflict peacefully. Countries across the world have been expelling the Maduro regime ambassadors and inviting Guaidó representatives to join them, the latest being announced by Salvadoran President NayibBukele, who has kicked out Nicolas Maduro's diplomatic corps (D.W., 2020).

In essence, while there have been sanctions, investigations, and standoff where the U.N. has been accused of 'stepping its boundaries,' the situation is not anywhere close to de-escalation. The reason is that a consensus needs to be reached by the members of the Security Council. However, in reality, the council is not a true representation of the world, and with the power-nations' own agendas, coming to a unanimous agreement that would take the organization forward has proven to be unlikely. And even if the U.N. were to ultimately allow the use of force, it wouldn't be without consequences (Thakur, 2016). With Venezuela not welcoming foreign assistance, may be up to Venezuela to solve their own crisis. Just as Rosemary DiCarlo states, "Venezuela is mired in a protracted deepening crisis that only Venezuelans can resolve." (Peace and Secutrity, 2020)

\section{Humanitarian Relief Efforts by WFP, UNHCR, UNICEF}

While the U.N. has not been able to resolve the democracy crisis completely, one thing that has been carried out quite effectively and efficiently, until the alleged 'coup attempt', was the relief the U.N. provided to those affected by the economic meltdown. Through its sister agencies, such as the World Food Program, United Nations High Commissioner for Refugees, and United Nations Children's Fund, aid has been sent with medical supplies, sanitary products, nutritional items, and food. The Humanitarian Response Plan for Venezuela (HRP), initiated in October 2018 has strategically responded to their most pressing humanitarian needs. 348 tons of medicine and medical supplies were distributed to their hospitals, 203 education centers have been supported, benefiting an estimated $85 \mathrm{~K}$ students, $4.5 \mathrm{~K}$ curative treatments for acute malnutrition were provided and 12,132 people were reached for food assistance. (Humanitarian Program Cycle 2019.) Other agencies have also been working closely with other governments of Mexico, Bangladesh, El Salvador, EU to respond to the humanitarian crisis.

The World Food Program, a food-assistance branch of the U.N., has a mission to "saving lives and changing lives, delivering food assistance in emergencies and working with communities to improve nutrition and build resilience" (WFP, 2020). The Maduro administration has actually allowed the WFP to carry out its operation. Through the standard WFP Emergency Food Security Assessment (EFSA) methodology, the WFP announced that about $7.9 \%$ of the Venezuelan population were severely food insecure, highlighting that nearly 2.3 million people have been worried about putting food on the table for their families. $24.4 \%$ are moderately concerned but have to make sacrifices to provide, nearly $74 \%$ of the population has to change their diet to eat daily, and $65 \%$ have to let go of essential items to pay for food items. Yet, seven out of ten Venezuelans say that food is available. This gives us insight into the fact that resource isn't the issue; the issue is that access to food is 
limited and the prices are much too high for many households to pay for. Thus, the problem can be traced back to hyperinflation and economic mismanagement by the government.

The United Nations High Commissioner for Refugees (UNHCR; the UN Refugee Agency) has the mission to "safeguard the rights and wellbeing of refugees." According to the UNHCR statistics, in 2019, 3.6 million Venezuelans opted to immigrate, and the figure rose to 5.5 million in 2020 (Morales-Zurita et al., 2020). Many have been reportedly displaced due to violence, threats of food insecurity, lack of medical supplies, access to essential items, and the onset of political instability and socioeconomic disturbances. The BBC reported that the number of children on the streets and in shelters has increased up to $50 \%$ since 2016 , and "food has become a source of conflict in poor families" says Fernando Pereira of CECODAP, a defender of the rights of children and adolescents (Brown, K. 2018). The youth interviewed on the streets of Caracas revealed that some chose to leave their home for the sake of their families because the food was never enough and that they have experienced conflict stemming from a shortage of food, such as abuse.

The UNICEF has vowed to protect children globally, but the organization's efforts to do so for the youth of Venezuela has not been well received by the Venezuelan government has not responded well towards the body because UNICEF highlighted cases of child abuse, sexual violence, and mistreatment of children across Venezuela (World Report 2020, 2020). UNICEF has been striving to protect children around that world regardless of gender, religion, race, or economic background. While the agency claims to have been "learning from experience," it needs to do more.

\section{Peacekeeping}

The UN's Peacekeeping force is said to be proven to "one of the most effective tools available to the international community to respond to the challenges of global peace and security" (UN Peacekeeping: A Year in Review, 2020). It is made up of 110,000 peacekeepers from over 120 countries and is invested in security, peace, and stability. It is based on principles of consent, impartiality, and use of force only in the cases of self-defense. The UN Peacekeeping force has an allocated budget of $\$ 7.3$ billion which makes up about $0.5 \%$ of global expenditures related to the military. The force is to be deployed by the U.N.S.C. and is currently conducting 13 operations across Western Sahara, Central African Republic, Mali, Congo, Lebanon, and the Middle East. The forces have been facilitated by the political process and should maintain political laws, protect civilian personnel, believe in disarmament, reintegration, and demobilization. The UN Peacekeeping has been termed eight times as cost-effective as the U.S military forces as reported by the US Government Accountability Office. The United Nations has categorized past missions in Liberia, Sierra Leone, Burundi, Cote d'Ivoire, and Haiti as "successful" (Africa Renewal, 2018), however, the allegation has been made by at least 13 countries that peacekeeping members have acted with violence, sexual misconduct, and abuse of power towards women and children of Haiti, where one peacekeeping mission was deployed (Peltier, E. 2019).

Foreign Policy, Adrienne Arsht Latin America Center, and Florida International University collaborated on a high-level crisis simulation that focused on the consideration of viable alternative, and actionable strategies that can support multilateral dialogue, considering the influential state actors of Russia, Cuba, China, and Maduro regime's possible actions that can affect the democratic process development, and what actions can be taken by the interim president to leverage the situation ("Atlantic Council 2020"). Apart from highlighting the importance of an agile action plan, strategic mitigation, counter-progress to combat 
communicable disease outbreaks, and spill-over effects, the most important factor that came to the top was the possibility of a peacekeeping mission. Despite the stalemate that has persisted since January 19, 2019, the participants of the UN Security Council have repeatedly referred to the simulation and called for the UN assistance to deploy a peacekeeping mission, along with the humanitarian aid being provided by the WFP, WHO, UNHCR, and Human Rights Council. Taken into account the situational gravity, where the Maduro administration dispatched forces to establish control, but with a loose grip, the collectives splintered to form factions. Allying with the terrorist groups, drug dealers, smugglers, and armed groups, the factions formed territories in Apure, Zulia, Tachira, giving way to anarchy, smuggling, terrorism, and human trafficking. With the Maduro regime no longer in control over the factions, plunged into a deep state of inaction, that enhanced the economic meltdown. The evidence from the irregular warfare has been brought under review by the US, Canada, Germany, Belgium, and the EU, but the permanent member Russia, and China along with Cuba, have been strong supporters of Maduro. The US has even hinted willingness to pursue an intervention without UN backing, with Brazil, Ecuador, Chile, and Peru under the vis-à-vis- the Libyan and Syrian conflict. The SC, however, has not been able to devise a contingency plan, and the security situation is further declining at an exponential pace. While the US maintains its stance, clearly stated in the UN, the international stakeholders have warned against the actions. The democratic process demands mitigation, and while the situation is dire, the warfare can accelerate the crisis, essentially dragging the state-actors amid an all-out war, which no one can afford in the connected, modern geopolitical sphere.

\section{Conclusion}

The United Nations has been one of the most prestigious organizations in the world with the figure-role to embody the ideals of democracy, peace, and be the people's voice across the globe. Venezuela's situation demands firm policy action to promptly investigate the issues and decide on the subject matter promptly. The investigation was started by Resolution 42/25, which was instigated by the Human Rights Council. Still, the long duration of the process clearly shows the inability of the U.N. to resolve the crisis effectively and efficiently. The U.N. is bound by global politics which makes separating national agendas and plans for the good of the globe, extremely difficult.

While the U.N. cannot resolve the conflict entirely, the body has placed sanctions that have been able to restrict the expansion of the Maduro regime. The public bodies of the U.N. like the WHO, HRC, UNHCR, and UNICEF have been providing relief amid the humanitarian crisis and the global pandemic. Hence, we may conclude that the U.N. has been a partial success in its mission. However, there needs to be a more focused approach to solve the root cause of the problem rather than just treating the symptoms. There is indeed a way to devise a strategy that allows the principal organs to handle the economic and democratic crisis by taking the lead and using the authority bestowed upon them. The U.N. needs to prioritize the survival and wellbeing of Venezuela's vulnerable people and set aside personal motives for the good of the falling country. The U.N. has successfully delivered aid and helped put the issue on a global platform so that it can be addressed effectively. However, as addressed in the paper, there are many aspects that the organization needs to remedy to be better equipped to solve Venezuela's crisis. 


\section{References}

Africa Renewal. (2018, April 7). Mission accomplished: 15 years of peacekeeping success in Liberia. Sierra Leone Times .https://www.sierraleonetimes.com/news/256947549/mission-accomplished-15-years-ofpeacekeeping-success-in-liberia

Akers, B., \&amp; Schrager, A. (2019, March 21). How Socialism Destroyed Venezuela. Retrieved January 01, 2021, from https://economics21.org/how-socialism-destroyed-venezuela

Aljazeera News. (2020). Venezuela 'failed coup plot': What we know so far | United States | Al Jazeera. https://www.aljazeera.com/news/2020/5/6/venezuela-failed-coup-plot-what-we-know-so-far

BBC. (2019, October). Venezuela wins seat on U.N. Human Rights Council - BBC News. BBC. https://www.bbc.com/news/world-latin-america-50087394

Bean, A. M. (2016). Venezuela, human rights and participatory democracy. Critical Sociology, 42(6), 827-843.

Bolopion, P. (2019, October 28). Venezuela's Infiltration of the U.N. Human Rights Council | Human Rights Watch. Human Rights Watch . https://www.hrw.org/news/2019/10/28/venezuelas-infiltration-un-humanrights-council\#),

Brown, J. (2018). Escaping the confines of market democracy: lessons from Venezuela. Socialism and Democracy, 32(2), 14-31.

Brown, K. (2018, November 2). Venezuela crisis: Mothers giving away babies, children living on streets. https://www.bbc.com/news/av/world-latin-america-45879534

Bureau of Western Hamisphere Affairs. (2020). Venezuela: A Democratic Crisis - United States Department of State. https://www.state.gov/a-democratic-crisis-in-venezuela

CIA. (2020). South America:: Venezuela - The World Factbook - Central Intelligence Agency. https://www.cia.gov/library/publications/the-world-factbook/geos/ve.html

Council, H. R. (2017). General Assembly. International Organization, 11(4), 649-655. https://doi.org/10.1017/s0020818300024334

Crawford, J., James, C., \& others. (2002). The International Law Commission's articles on state responsibility: introduction, text and commentaries. Cambridge University Press.

Deliver Humanitarian Aid. Retrieved January 02, 2021, from https://www.un.org/en/sections/what-wedo/deliver-humanitarian-aid/index.html

De Wet, E. (2004). The Chapter VII Powers of the United Nations Security Council (Vol. 3). Hart Publishing.

DW. (2020). El Salvador expels Venezuelan diplomats, recognizes Juan Guaido | News | D.W. | 03.11.2019.

D.W. Made of Minds .https://www.dw.com/en/el-salvador-expels-venezuelan-diplomats-recognizes-juanguaido/a-51095475

Escobari, M. (2019, February 28). Made by Maduro: The Humanitarian Crisis in Venezuela and US Policy Responses. $\quad$ https://www.brookings.edu/testimonies/made-by-maduro-the-humanitarian-crisis-invenezuela-and-us-policy-responses/

Focus Economics. (2020). Venezuela Economy - GDP, Inflation, CPI and Interest Rate. https://www.focuseconomics.com/countries/venezuela 
Volume 9 Issue 3 March 2021

Gamboa, L. (2017). Opposition at the Margins: Strategies against the Erosion of Democracy in Colombia and Venezuela. Comparative Politics, 49(4), 457-477.

Garb, M. (2014). Evaluating the success of peace operations. Scientia Militaria: South African Journal of Military Studies, 42(1), 44-63.

Gott, R. (2000). In the shadow of the liberator: Hugo Chávez and the transformation of Venezuela. Verso.

Hodgkinson, T., Andresen, M. A., \& Farrell, G. (2016). The decline and locational shift of automotive theft: A local level analysis. Journal of Criminal Justice, 44, 49-57. https://doi.org/10.1016/J.JCRIMJUS.2015.12.003

Humanitarian Program Cycle 2019. HUMANITARIAN RESPONSE PLAN VENEZUELA [PDF]. https://reliefweb.int/sites/reliefweb.int/files/resources/20190814_HRP_VEN_EN.pdf.

Kalantar, N. (2019). The Limitations and Capabilities of the United Nations in Modern Conflict.

Kiger. P. (2019, May 9). How Venezuela Fell from the Richest Country in South America into Crisis. https://www.history.com/news/venezuela-chavez-maduro-crisis

Lederer, E. (2019, October 17). Venezuela wins seat on UN human rights body despite opposition. https://www.pbs.org/newshour/world/venezuela-wins-seat-on-un-human-rights-body-despite-opposition

Maintain International Peace and Security. Retrieved January 2, 2021, from https://www.un.org/en/sections/what-we-do/maintain-international-peace-and-security/index.html

McCarthy, J. (2006, December 3). Chavez Reaches Out with 'Bolivarian Missions'. https://www.npr.org/templates/story/story.php?storyId=6572676

Morales-Zurita, L. F., Bonilla-Mej'lia, L., Hermida, D., Floréz, L. A., Bonilla-Mej'`lia, L., Morales, L. F., Hermida-Giraldo, D., \&Flórez, L. A. (2020). The Labor Market of Immigrants and Non-Immigrants Evidence from the Venezuelan Refugee Crisis. Borradores de Econom $\bigwedge \backslash i$; a; No. 1119.

Mu, XZ., Hu, GW. (2018, January 24) Analysis of Venezuela's oil-oriented economy: from the perspective of entropy. https://doi.org/10.1007/s12182-018-0215-4

Nal'lim, M., \& Toro, F. (2018). Venezuela's Suicide. Foreign Aff., 97, 126.

News Wires. (2019, June 27). Venezuela government says it derailed a coup attempt, opposition denies. France 24. https://www.france24.com/en/20190627-venezuela-coup-nicolas-maduro-juan-guaido

Ofman, D. (2016, July 6). Hugo Chávez's legacy looms over Venezuela's economic crisis. https://www.pri.org/stories/2016-07-06/hugo-chavezs-legacy-looms-over-venezuela-s-economic-crisis

Peace and Secutrity. (2020). Only Venezuelans can resolve Venezuela's deepening crisis, DiCarlo tells Security Council|| U.N. News. https://news.un.org/en/story/2020/05/1064602

Pelcher, H. (2020). - Venezuela - Gross domestic product (GDP) 2019 | Statista. https://www.statista.com/statistics/370937/gross-domestic-product-gdp-in-venezuela/

Peltier, E. (2019, December 18). U.N. Peacekeepers in Haiti Said to Have Fathered Hundreds of Children. https://www.nytimes.com/2019/12/18/world/americas/haiti-un-peacekeepers.html

Roth, R. (2019, October 18). Venezuela wins seat on UN Human Rights Council. https://www.cnn.com/2019/10/17/world/venezuela-wins-seat-on-united-nations-human-rights-councilintl/index.html

Scannella, P., \& Splinter, P. (2007). The United Nations Human Rights Council: A Promise to be Fulfilled. 
Volume 9 Issue 3 March 2021

Thakur, R. (2016). The United Nations, peace and security: from collective security to the responsibility to protect. Cambridge University Press.

Trading Economics. (2020). Venezuela GDP Annual Growth Rate | 1998-2019 Data | 2020-2022 Forecast | Historical. https://tradingeconomics.com/venezuela/gdp-growth-annual

TRT World News/Magazine. (2020, Sep 22). The United Nations has a problem, and no one's talking about it. https://www.trtworld.com/magazine/the-united-nations-has-a-problem-and-no-one-s-talking-about-it39961

UN: Deny Rights Council Seats to Major Violators. (2020, October 28). https://www.hrw.org/news/2020/10/08/un-deny-rights-council-seats-major-violators

U.N. News. (2020, August 23). Fresh allegations of sexual abuse made against U.N. peacekeepers in Central African Republic | Africa Renewal. Africa Renewal . https://www.un.org/africarenewal/news/freshallegations-sexual-abuse-made-against-un-peacekeepers-central-african-republic

UN Human Rights Council: History \& Overview. https://www.jewishvirtuallibrary.org/history-and-overviewof-the-un-human-rights-council

U.N. Watch. (2020). Anti-Israel Resolutions at the HRC - U.N. Watch. U.N. Watch .https://unwatch.org/antiisrael-resolutions-hrc/

United Nations Sustainable Development Goals. Retrieved January 02, 2021, from https://wdo.org/about/visionmission/un-sdgs/

United Nations S/PV.8476 Security Council Seventy-fourth year 8476th meeting [PDF]. (2019, February 28). New York.

U.S. Embassy Caracas | 18 October, 2. (2019, October 18). Statement by U.S. Representative to the United Nations Ambassador Kelly Craft. https://ve.usembassy.gov/statement-by-u-s-representative-to-the-unitednations-ambassador-kelly-craft/

UN PEACEKEEPING: A YEAR IN REVIEW Peacekeeping. https://peacekeeping.un.org/en/un-peacekeepingyear-review- 0

OHCHR | Independent International Fact-Finding Mission on the Bolivarian Republic of Venezuela Independent International Fact-Finding Mission on the Bolivarian Republic of Venezuela, Pub. L. No. Resolution 42/25, United Nations Human Right Council (2020). https://www.ohchr.org/EN/HRBodies/HRC/FFMV/Pages/Index.aspx

United Nations. (2020, November 1). About the U.N. | United Nations. United Nations . https://www.un.org/en/about-un/

United Nations Refugee Agency. (2019). Venezuela Situation (Issue April). http://reporting.unhcr.org/sites/default/files/UNHCR Update on Venezuela Situation - March 2019.pdf

Venezuela: A Democratic Crisis - United States Department of State. (2020, December 1). https://www.state.gov/a-democratic-crisis-in-venezuela

WFP. (2020, October 21). United Nations World Food Programme (WFP) - WFP.org. World Food Program . https://www.wfp.org/

World Report 2020. (2020). World Report 2020: Venezuela | Human Rights Watch. https://www.hrw.org/worldreport/2020/country-chapters/venezuela 
iJournals: International Journal of Social Relevance \& Concern (IJSRC)

ISSN-2347-9698

Volume 9 Issue 3 March 2021

Yenigun, C. M. (2016). Evolution Dilemma of the United Nations. International Journal of Research in Business and Social Science (2147-4478), 5(1), 65-75.

2020 Index of Economic Freedom. (2020). Venezuela. https://www.heritage.org/index/country/venezuela.

\section{Appendix A}

\section{OVERALL SCORE}
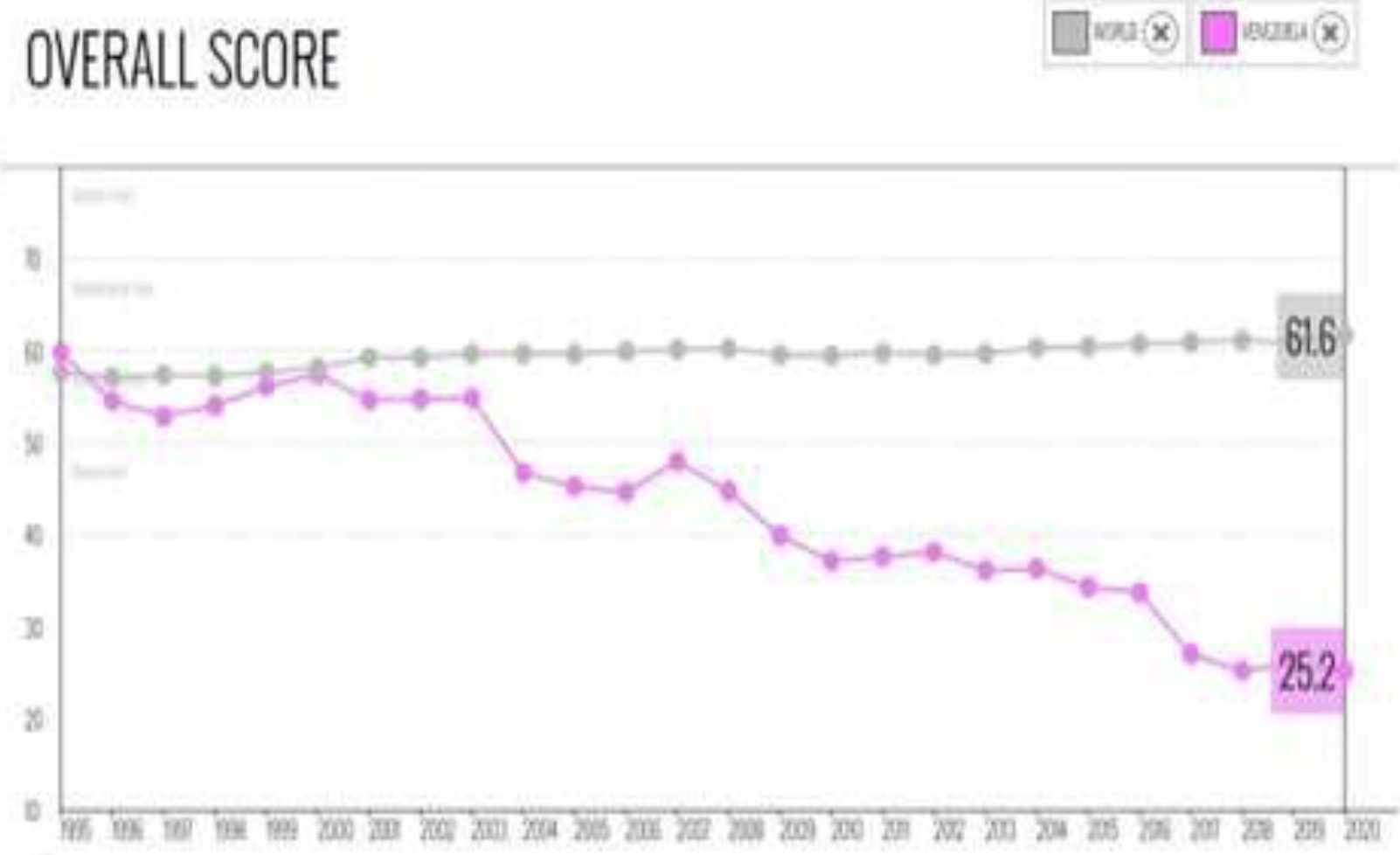

GOVERNMENT

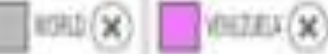

INTEGRTY

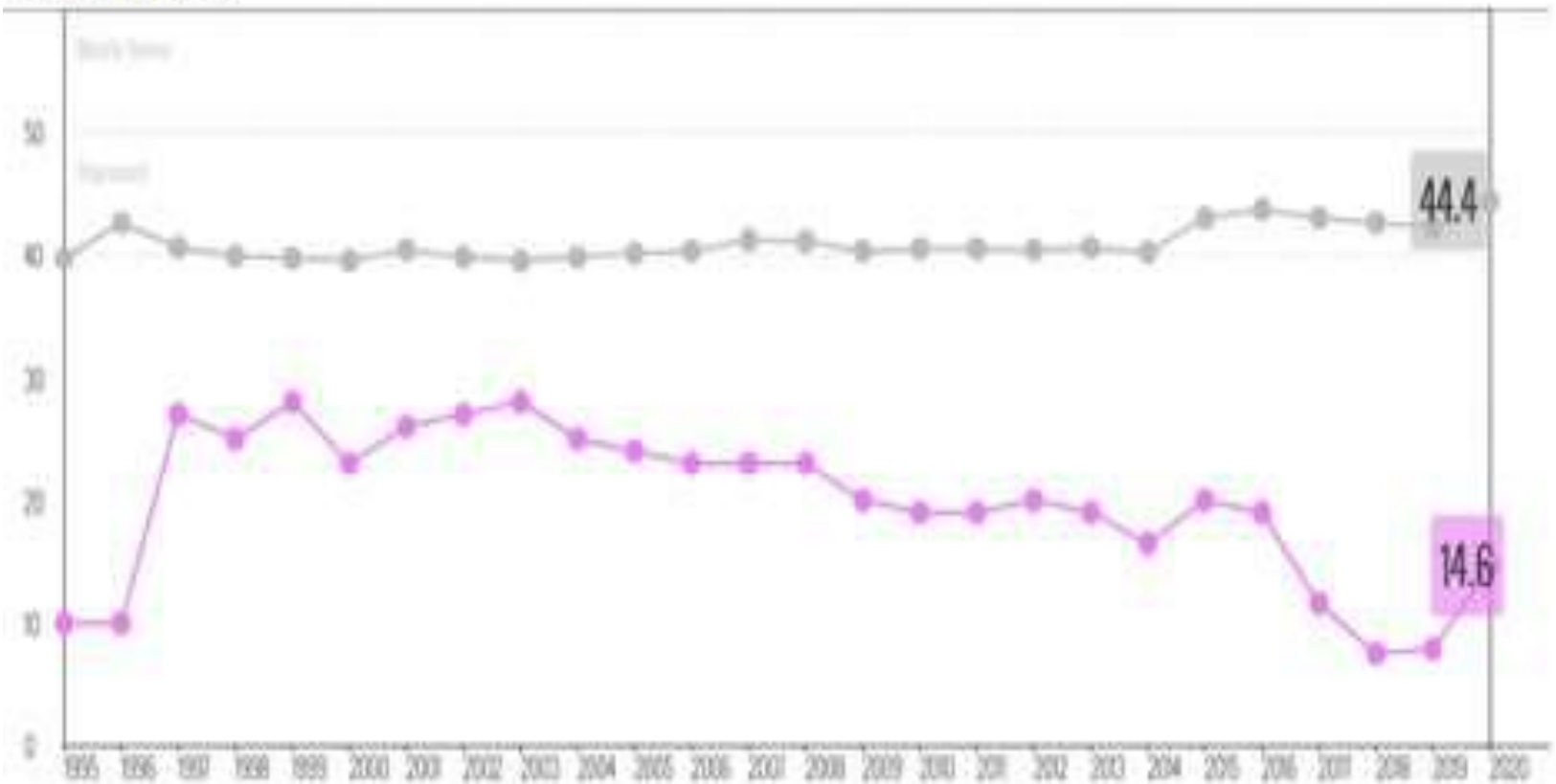




\section{Appendix B}

Venezuela Economy Data Courtesy of (Focus Economics, 2020)

\begin{tabular}{|c|c|c|c|c|c|}
\hline & 201 & 20 & $\begin{array}{l}20 \\
17\end{array}$ & 2018 & 201 \\
\hline $\begin{array}{l}\text { Population } \\
\underline{\text { (million) }}\end{array}$ & 30. & 30 & 30 & 28.9 & 27. \\
\hline $\begin{aligned} \text { GDP per } \\
\text { capita (USD) }\end{aligned}$ & 568 & $\begin{array}{l}9, \\
092 \quad\end{array}$ & $\begin{array}{l}4, \\
755 \quad\end{array}$ & $\begin{array}{l}3,41 \\
1\end{array}$ & - \\
\hline $\begin{array}{ll}\text { GDP (USD } \\
\text { bn) }\end{array}$ & 324 & 27 & 14 & 98.4 & - \\
\hline $\begin{array}{l}\text { Economic } \\
\text { Growth (GDP, annual } \\
\text { variation in } \%)\end{array}$ & 6.2 & 17.0 & 15.7 & -19.6 & - \\
\hline \begin{tabular}{l}
\multicolumn{2}{c}{ Domestic } \\
Demand $\quad($ annual \\
variation in \%)
\end{tabular} & 11.8 & 26.3 & & -18.2 & - \\
\hline $\begin{array}{lr} & \begin{array}{r}\text { Consumption } \\
\text { (annual } \\
\text { in } \% \text { ) }\end{array} \\
\underline{\text { inariation }} \\
\end{array}$ & 8.9 & & 16.2 & -20.1 & - \\
\hline $\begin{array}{lr} & \begin{array}{l}\text { Investment } \\
\text { (annual } \\
\text { in } \% \text { ) }\end{array} \\
\underline{\text { variation }}\end{array}$ & 20.4 & 45.1 & 45.3 & -37.5 & - \\
\hline $\begin{array}{l}\text { Manufacturin } \\
\mathrm{g} \quad \text { (annual variation } \\
\underline{\text { in } \%)}\end{array}$ & 5.4 & - & - & - & - \\
\hline $\begin{array}{lr} & \begin{array}{l}\text { Retail Sales } \\
\text { (annual }\end{array} \\
\underline{\text { in } \% \text { ) }} & \\
\end{array}$ & - & - & - & - & - \\
\hline$\underline{\text { nt Rate }} \underline{\text { Unemployme }}$ & 6.8 & 7. & 2 & 6.9 & - \\
\hline
\end{tabular}


Volume 9 Issue 3 March 2021

\begin{tabular}{|c|c|c|c|c|c|c|c|c|c|c|}
\hline $\begin{array}{c}\underline{\text { Fiscal }} \\
\text { Balance (\% of GDP) }\end{array}$ & 15.6 & - & 16.8 & & 18.2 & & & - & & \\
\hline$\underline{\text { Public Debt }}$ & & 74. & & 92 & 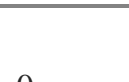 & 12 & & - & & - \\
\hline \begin{tabular}{lc} 
& \multicolumn{2}{c}{ Money } \\
(annual & variation \\
$\underline{\text { in \%) }}$ & \\
\end{tabular} & & 101 & 9 & 15 & 121 & 1, & 57 & 63,2 & 46 & 4,9 \\
\hline \begin{tabular}{ll} 
& \multicolumn{1}{l|}{ Inflation } \\
Rate & $(\mathrm{CPI}, \quad$ annual \\
variation in \%, eop)
\end{tabular} & & 181 & 4 & 27 & 3 & 86 & 060 & 130 & 85 & 9,5 \\
\hline \begin{tabular}{lc} 
& \multicolumn{1}{|l}{ Inflation } \\
Rate & $(\mathrm{CPI}, \quad$ annual \\
variation in $\%)$
\end{tabular} & & 122 & 5 & 25 & 8 & 43 & 74 & 65,3 & 906 & 19 , \\
\hline \begin{tabular}{|l|}
\multicolumn{1}{c|}{ Inflation } \\
$($ PPI, annual variation \\
$\underline{\text { in \%) }}$
\end{tabular} & & - & & & & & & - & & - \\
\hline $\begin{array}{r}\text { Benchmark } \\
\text { Interest Rate (\%) }\end{array}$ & 59 & 14 & & & .77 & 14 & 0 & 15.0 & 00 & 24. \\
\hline $\begin{array}{lr} & \frac{\text { Stock Market }}{\text { (annual }} \\
\text { variation } \\
\underline{\text { in \%) }}\end{array}$ & & 278 & 7 & 11 & 884 & 3, & 985 & 126 & 21 & 5,5 \\
\hline $\begin{aligned} \underline{\text { Exchange }} \\
\underline{\text { Rate (vs USD) }}\end{aligned}$ & 0 & 6.3 & .00 & 10 & .00 & 10 & 2 & 638. & $\mid 621$ & 46 , \\
\hline $\begin{array}{c}\text { Exchange } \\
\text { Rate (vs USD, aop) }\end{array}$ & 0 & 6.3 & 29 & 9. & .00 & 10 & 4 & 81.9 & 910 & 15, \\
\hline $\begin{array}{c}\underline{\text { Current }} \\
\underline{\text { Account }(\% \text { of GDP })}\end{array}$ & 5.6 & - & 0.4 & - & 1 & 6. & & 8.7 & & - \\
\hline \begin{tabular}{l}
\multicolumn{2}{c}{ Current } \\
Account $\quad$ Balance \\
$\underline{\text { USD bn) }}$
\end{tabular} & 16.1 & - & 3.9 & & 7 & 8. & & 8.6 & & - \\
\hline
\end{tabular}


iJournals: International Journal of Social Relevance \& Concern (IJSRC)

ISSN-2347-9698

Volume 9 Issue 3 March 2021

\begin{tabular}{|c|c|c|c|c|c|}
\hline $\begin{array}{c}\underline{\text { Trade }} \\
\text { Balance (USD billion) }\end{array}$ & 3.9 & $\begin{array}{ll} & 11 \\
.0 & \end{array}$ & $\begin{array}{ll} & 22 \\
.0 & \end{array}$ & 20.9 & - \\
\hline $\begin{array}{l}\text { Exports } \\
\text { (USD billion) }\end{array}$ & 37. & .4 & .0 & 33.7 & - \\
\hline $\begin{array}{l}\underline{\text { Imports }} \\
\text { (USD billion) }\end{array}$ & 33. & .4 & .0 & 12.8 & - \\
\hline \begin{tabular}{lc} 
& \multicolumn{1}{c}{ Exports } \\
(annual & variation \\
in \%) & \\
\end{tabular} & 50.1 & 26.4 & 24 & -1.0 & - \\
\hline \begin{tabular}{lr} 
& \multicolumn{1}{c}{ Imports } \\
(annual & variation \\
in \%) & \\
\end{tabular} & 29.5 & 50.9 & 26.6 & 6.5 & - \\
\hline $\begin{array}{l}\text { International } \\
\text { Reserves (USD) }\end{array}$ & 16. & 11 & & 8.8 & 7.5 \\
\hline $\begin{array}{r}\text { External } \\
\text { Debt (\% of GDP) }\end{array}$ & 38. & & 78 & 110 & - \\
\hline
\end{tabular}

